\title{
PENGARUH PENDIDIKAN DAN PELATIHAN, PENGALAMAN ORGANISASI, PEMAHAMAN TENTANG ANGGARAN TERHADAP PERAN ANGGOTA DPRD DALAM PENGAWASAN KEUANGAN DAERAH (STUDI PADA ANGGOTA DPRD KOTA MANADO, KOTA BITUNG DAN PROVINSI SULAWESI UTARA)
}

\author{
Reynaldi Dionisius Wowor ${ }^{1}$, Hendrik Manossoh $^{2}$, Heince R. N. Wokas ${ }^{3}$ \\ 1,2,3 Jurusan Akuntansi, Fakultas Ekonomi dan Bisnis, Universitas Sam Ratulangi, Jl.Kampus Bahu, Manado, \\ 95115, Indonesia \\ E-mail : rexdion.wowor@gmail.com
}

\begin{abstract}
This study aims to examine the influence of education and training, organizational experience, knowledge about budget towards the role of DPRD's members on financial region supervision. This research is motivated by the facts based on the fact that there is still a weakness in the supervision of regional finances. Dependent variable in this research are the role of DPRD's members on financial region supervision. Independent variables are education and training, organizational experience,knowledge about budget. The data in this research consist of primary data that taken by the questionnaires which distributed directly to respondents. The data are collected from 60 respondents of DPRD members of Manado City, Bitung City and North Sulawesi Province. The Hipothesis of this study are examine by using the multiple linear regression. The result of this research is indicated that is first, education and training have not effect towards the role of DPRD's members on financial region supervision. Second, organizational experience have not effect towards the role of DPRD's members on financial region supervision. Third, knowledge about budget affect towards the role of DPRD's members on financial region supervision. The Suggestion for further research is the research instrument of education and training variable, organizational experience variable should be developed.

Keywords : Education and Training, Organizational Experience, Knowledge about Budget, The Role of DPRD Members, Financial Region Supervision.
\end{abstract}

\section{PENDAHULUAN}

Otonomi daerah baru yang tercantum pada UU No.23 Tahun 2014 tentang Pemerintah Daerah menjadikan kekuasaan dan tanggungjawab yang dibebankan kepada pemerintah pusat yang debebankan kepada pemerintah daerah supaya mengelola daerahnya sendiri dengan maksimal. UU itu merubah akuntabilitas atau pertanggungjawaban pemerintah daerah dari pertanggungjawaban pusat ke pertanggung jawaban DPRD, sehingga pengelolaan keuangan daerah menjadi jelas. Manajemen keuangan daerah saat ini menjadi tanggung-jawab penuh pemerintah daerah dan DPRD bertugas mengawasi jalannya Anggaran Pendapatan dan Belanja Daerah. Anggota DPRD memiliki peranan yang sangat besar dalam mengawasi kebijakan-kebijakan yang diambil dalam APBD agar setiap pengeluaran yang di keluarkan tetap ekonomis, efisien serta efektif, transparan dan akuntabel.

Pemerintah dalam hal ini adalah DPRD Kota Bitung, Manado dan Provinsi Sulawesi Utara nyatanya masih ada permasalahan dan kelemahan pengelolaan keuangan daerah yang mengakibatkan program kerja yang telah ada belumlah terealisasi seperti dengan prioritas daerah. Opini yang dikeluarkan oleh BPK RI perwakilan provinsi Sulawesi Utara atas 
laporan keuangan pemerintah daerah Kota Manado tahun anggaran 2005-2012 cenderung menunjukan opini yang kurang memuaskan.

Badan Pemeriksa Keuangan perwakilan Sulawesi Utara menemukan permasalahan atas Laporan Keuangan Pemerintah Daerah (LKPD) Kabupaten dan Kota tahun 2016 yang mempengaruhi pemberian opini. Kata Kepala BPKP Prov. Sulawesi Utara persoalan yang ditemukan berkaitan dengan beberapa hal diantaranya kelebihan pembayaran pekerjaan yang seharusnya belum bisa dibayarkan karena pekerjaannya belum selesai. Selanjutnya, pembayaran honor tidak sesuai dengan peraturan. Hal itu menyebabkan beberapa entitas opini Wajar Dengan Pengecualian (WDP) ataupun tidak memberikan pendapat atau disclaimer.

Anggota DPRD memiliki peranan yang sangat penting dalam mengawasi kebijakankebijakan yang diambil dalam APBD agar setiap pengeluaran yang di keluarkan tetap ekonomis, efisien serta efektif, transparan dan akuntabel. Dalam melaksanakan pengawasan keuangan daerah, setiap anggota DPRD memiliki sistem individu masing-masing. Setiap individu memiliki latar belakang yang berbeda-beda dan mungkin dapat mempengaruhi tugasnya sebagai anggota dewan sehingga perlu ditelaah lebih dalam mengenai variabel yang mempengaruhi kinerja DPRD dalam mengawasi keuangan daerah. Variabel tersebut meliputi personal background yang terdiri dari pendidikan dan pelatihan, pengalaman organisasi, dan pemahaman tentang anggaran.

\section{TINJAUAN PUSTAKA}

\subsection{Akuntansi Pajak}

Akuntansi merupakan suatu proses dari transaksi ekonomi yang diawali dengan pencatatan, pengolongan dan pengikhtisaran serta di akhiri dengan suatu pengambilan keputusan (Romney \& Steinhart $2015: 5$ ).

\subsection{Akuntansi Pemerintahan}

Sujarweni (2015: 18) berpendapat akuntansi pemerintahan merupakan akuntansi memiliki sangkutpaut dengan bidang keuangan negara, yang dimulai dari anggaran sampai dengan pelaksanaan dan pelaporannya, serta segala pengaruh yang muncul.

\subsection{Dewan Perwakilan Rakyat Daerah (DPRD)}

Dewi (2011) berpendapat bahwa DPRD adalah lembaga legislatif punya hak budget (hak tetapkan anggaran juga melakukan pengawasan pelaksanaan APBD). DPRD merupakan perwakilan dari rakyat daerah yang mempunyai tugas yang penting dalam merencanakan serta mengawasi kuangan daerah.

\subsubsection{Pendidikan, Pelatihan dan Pengalaman Organisasi}

Pendidikan dari anggota DPRD yaitu tingkat pendidikan formal yang dimiliki oleh setiap anggota DPRD berupa pendidikan yang baku mulai dari SD sampai perguruan tinggi dan pendidikan nonformal. Sedangkan pelatihan yang penulis maksud disini adalah sejumlah pelatihan yang pernah diikuti oleh anggota DPRD yang bertujuan untuk meningkatkan kapabilitas anggota DPRD dalam pelaksanaan fungsinya.

Pengalaman organisasi anggota DPRD di berbagai organisasi yang diikuti anggota DPRD sebelum terpilih menjabat jadi wakil rakyat di DPRD. Pengalaman organisasi ini terdiri dari LSM, non LSM, organisasi politik, akademisi, ormas, dan sebagainya. Hubungan yang terjadi dalam suatu organisasi tersebut akan menciptakan interaksi sosial. Interaksi yang baik akan tercipta apabila setiap individu memahami tugas dan peran masing-masing dalam organisasi tersebut. Dengan begitu, maka individu tersebut dapat berlatih berinteraksi dengan orang satu dengan yang lain. Sehingga dapat disimpulkan bahwa pengalaman organisasi merupakan pengalaman seseorang menjadi anggota dalam kepengurusan suatu organisasi (Amalia, $2013: 36$ ). 


\subsection{Pemahaman Anggota DPRD Tentang Anggaran}

Pemahaman dari setiap individu anggota DPRD pada anggaran keuangan daerah diartikan sebagai pengetahuan pada susunan anggaran mulai dari perencanaan sampai tahap selesai. Pengetahuan anggota DPRD terhadap UU yang atur pengelolaan APBD. APBD merupakan perencanaan keuangan daerah untuk digunakan dibidang infrakstuktur, sosial, kesehatan dan lain-lain yang memerlukan persetujuan dari DPRD dalam melaksanakannya yang telah diatur didalam UU No 17 thn 2003 Pasal 1 Butir 8 Tentang Keuangan Negara.

\subsection{Pengawasan Keuangan Daerah}

Pengawasan keuangan daerah adalah pengawasan terhadap APBD. Pengawasan keuangan daerah bertujuan untuk mengontrol semua kebijakan perencanaan APBD sudah sesuai dengan kebutuhan daerah dan masyarakat didalamnya.

\subsubsection{Kerangka Berpikir}

Pendidikan, pelatihan pengalaman organisasi dan pemahaman anggota DPRD dapat dijadikan sebagai tolak ukur dalam kinerjanya dalam melaksanakan pengawasan keuangan daerah oleh DPRD.

\subsection{Hipotesis Penelitian}

Berdasarkan teori-teori sertan kerangka berpikir peneliti, maka hipotesis penelitian sebagai berikut:

$\mathrm{H}_{1}$ : Pendidikan dan pelatihan berpengaruh secara signifikan terhadap peran anggota DPRD dalam pengawasan keuangan daerah.

$\mathrm{H}_{2}$ : Pengalaman organisasi berpengaruh secara signifikan terhadap peran anggota DPRD dalam pengawasan keuangan daerah.

$\mathrm{H}_{3}$ : Pemahaman anggota DPRD tentang anggaran berpengaruh secara signifikan terhadap peran anggota DPRD dalam pengawasan keuangan daerah.

\section{METODE PENELITIAN}

\subsection{Jenis Penelitian}

Jenis penelitian yang digunakan dalam penelitian ini menggunakan pendekatan deskriptif kemudian dianalisis dengan metode kuantitatif.

\subsection{Tempat dan Waktu Penelitian}

Tempat dan waktu penelitian pada beberapa kantor DPRD seperti Kantor DPRD Provinsi Sulawesi Utara, Kantor DPRD Kota Manado dan Kantor DPRD Kota Bitung. Waktu pelaksanaan penelitian dimulai pada bulan September 2017.

\subsection{Teknik Pengumpulan Data}

Metode pengumpulan data pada penelitian ini menggunakan teknik primer atau metode yang pengambilan data yang langsung dari subjek penelitian dengan menggunakan objek dari penelitian sebagai sumber dalam informasi yang dicari. Metode penyebaran kuesioner adalah Personally Administered Questionaires.

\subsection{Populasi dan Sampel}

Populasi dalam penelitian ini adalah anggota DPRD Kota Manado, Kota Bitung dan Provinsi Sulawesi Utara. Peneliti menggunakan metode pemilihan sampel (purposive sampling).

\subsection{Metode Analisis}

1. Analisis Statistik Deskriptif

Statistik deskriptif digunakan untuk analisis data dengan cara mendeskriptifkan, menggambarkan keadaan atau jawaban responden.

2. Uji Kualitas Data

a. Uji Validitas

Untuk mengetauhi apakah kuesioner dalam penelitian sudah sah dan pantas digunakan atau tidak. 
b. Uji Reliabilitas

Pengujian uji reliabilitas digunakan untuk mengetahui jika indikator variabel sudah konsisten dan tetap dari satu pertanyaan ke pertanyaan lainnya.

3. Uji Asumsi Klasik

a. Uji Normalitas

Uji normalitas digunakan untuk mengetauhi apakah variabel memberikan distribusi normal/tidak.

b. Uji Multikolinearitas

Uji multikolinearitas bertujuan menguji jika model regresi ada korelasi antara variabel bebas. Oleh karena itu, uji multikolinearitas digunakan pada penelitian yang mempunyai variabel bebas lebih dari satu. Model regresi yang baik harus tidak ada korelasi antara variabel bebas (independen).

c. Uji Heteroskedastisitas

Pengujian heteroskedastisitas digunakan menguji model regresi terjadi ketidaksamaan varians residual.

4. Analisis Regresi Linier Berganda

a. Uji t

Untuk uji hipotesis penelitian maka peneliti menggunakan uji t untuk melihat apakah variabel independen sudah mberikan pengaruh yang signifikan terhadap dependen.

b. Analisis regresi linear berganda

digunakan untuk mengetahui pengaruh antara pendidikan dan pelatihan (X1), pengalaman organisasi (X2), pemahaman tentang anggaran (X3), dan peran anggota DPRD dalam pengawasan keuangan daerah (Y).

\section{HASIL PENELITIAN DAN PEMBAHASAN}

\subsection{Gambaran Umum DPRD}

Dewan Perwakilan Rakyat Daerah (DPRD) adalah "Pemerintah daerah provinsi, daerah kabupaten dan kota memiliki Dewan Perwakilan Rakyat Daerah yang anggotaanggotanya dipilih melalui pemilihan umum". DPRD diatur didalam UU Nomor 17 Tahun 2014. DPRD merupakan lembaga yang mewakili rakyat daerah dalam mengautur unsur penyelenggara pemerintahan daerah provinsi. DPRD mempunyai kekuasaan dalam mengawasi serta merencanakan kebijakan atas keuangan daerah.

\subsection{Hasil Penelitian}

\subsubsection{Analisis Deskriptif Anggota DPRD}

Berdasar hasil penelitian pada anggota DPRD sebanyak 60 responden yang berada di Kota Bitung, Manado dan Provinsi Sulawesi Utara menunjukan bahwa dari 60 responden yang dilakukan penelitian, ada 39 orang responden $(65 \%)$ berjenis kelamin laki-laki dan 21 orang responden $(35 \%)$ berjenis kelamin perempuan. Sedangkan dari tingkat pendidikan responden ada 5 orang $(8,3 \%)$ yang berlatar belakang pendidikan SMA/Sederajat, 1 orang $(1,7 \%)$ berlatar belakang pendidikan D3/Diploma, 31 orang $(51,7 \%)$ berlatar belakang pendidikan S1/Sarjana, 18 orang (30\%) berlatar belakang pendidikan S2/Master, dan sebanyak 5 orang $(8,3 \%)$ berlatar belakang pendidikan S3/Doktor.

Analisis data berdasar pada jawaban responden dikumpul sebanyak 60 responden dari data diperoleh maka diketahui statistik deskriptif seperti pada tabel dibawah. 


\begin{tabular}{|c|r|r|r|r|r|}
\hline & N & Minimum & Maximum & Mean & $\begin{array}{c}\text { Std. } \\
\text { Deviation }\end{array}$ \\
\hline PP & 60 & 13.00 & 22.00 & 19.2333 & 2.14213 \\
PO & 60 & 16.00 & 25.00 & 20.7333 & 2.17744 \\
PDTA & 60 & 27.00 & 45.00 & 35.1833 & 3.87295 \\
Valid N (listwise) & 60 & & & & \\
\hline
\end{tabular}

Rata-rata menunjukan tendensi sentral dari distribusi skor jawaban responden. Perbandingan antara rata-rata dengan deviasi standar menunjukan dispersi skor jawaban responden. Normalitas distribusi skor jawaban responden ditunjukan dengan besar-kecilnya perbedaan antara nilai rata-rata dengan deviasi standarnya. Dari tabel di atas, maka dapat diketahui statistik deskriptif dari masing-masing variabel :

1. Variabel pendidikan dan pelatihan mempunyai nilai rata-rata sebesar 19,2333 dan nilai standar deviasinya sebesar 2.14213 .

2. Variabel pengalaman organisasi mempunyai nilai rata-rata sebesar 20,7333 dan nilai standar deviasinya sebesar 2.17744 .

3. Variabel pemahaman tentang anggaran mempunyai nilai rata-rata sebesar 35,1833 dan nilai standar deviasinya sebesar 3.87295 .

\subsubsection{Hasil Uji Kualitas Data}

a.Hasil Uji Validitas

\begin{tabular}{|c|c|c|c|}
\hline No. & Variabel & Pernyataan & Keterangan \\
\hline 1 & $\begin{array}{c}\text { Pendidikan dan } \\
\text { Pelatihan }\end{array}$ & PP1, PP2, PP3, PP4, PP5 & Valid \\
\hline 2 & Pengalaman Organisasi & PO1, PO2, PO3, PO4, PO5 & Valid \\
\hline 3 & $\begin{array}{c}\text { Pemahaman Anggota } \\
\text { DPRD Tentang } \\
\text { Anggaran }\end{array}$ & $\begin{array}{c}\text { PADTA1, PADTA2, PADTA3, PADTA4, } \\
\text { PADTA5, PADTA6, PADTA7, PADTA8, }\end{array}$ & Valid \\
& $\begin{array}{c}\text { PADTA9 } \\
\text { Peran Anggota DPRD } \\
\text { dalam Pengawasan } \\
\text { Keuangan Daerah }\end{array}$ & $\begin{array}{c}\text { PADPKD1, PADPKD2, PADPKD3, } \\
\text { PADPKD4, PADPKD5, PADPKD6, }\end{array}$ & Valid \\
& PADPKD7, PADPKD8, PADPKD9, & \\
\hline
\end{tabular}

Dari tabel di atas semua item pernyataan dinyatakan valid. Berarti setiap item pernyataan kuesioner tersebut adalah valid.

b.Hasil Uji Reliabilitas

\begin{tabular}{|c|c|c|c|}
\hline No. & Variabel & Cronbach's Alpha & Keterangan \\
\hline 1 & Pendidikan dan Pelatihan & 0,316 & Reliabel \\
\hline 2 & Pengalaman Organisasi & 0,611 & Reliabel \\
\hline 3 & Pemahaman Anggota DPRD Tentang \\
Anggaran & 0,667 & Reliabel \\
\hline 4 & $\begin{array}{c}\text { Peran Anggota DPRD dalam Pengawasan } \\
\text { Keuangan Daerah }\end{array}$ & 0,684 & Reliabel \\
\hline
\end{tabular}

Pada tabel di atas dapat dilihat bahwa nilai Cronbach's Alpha yang dihasilkan oleh variabel pendidikan dan pelatihan sebesar 0,316, pengalaman organisasi sebesar 0,611, pemahaman anggota DPRD tentang anggaran sebesar 0,667, dan peran anggota DPRD dalam pengawasan keuangan daerah sebesar 0,684. Semua variabel memiliki nilai $>0,60$. Hal ini berarti variabel pendidikan dan pelatihan, pengalaman organisasi, pemahaman anggota 
DPRD tentang anggaran, dan peran anggota DPRD dalam pengawasan keuangan daerah dapat dikatakan reliabel.

\subsubsection{Hasil Uji Asumsi Klasik}

a.Uji Normalitas

One-Sample Kolmogorov-Smirnov Test

\begin{tabular}{|cc|r|}
\hline & & $\begin{array}{c}\text { Unstandardized } \\
\text { Residual }\end{array}$ \\
\hline $\mathrm{N}$ & & 60 \\
Normal Parameters $^{\mathrm{a}, \mathrm{b}}$ & Mean & 0.0000000 \\
& Std. Deviation & 3.08217126 \\
Most Extreme Differences & Absolute & 0.146 \\
& Positive & 0.146 \\
Kolmogorov-Smirnov Z & Negative & -0.093 \\
Asymp. Sig. (2-tailed) & & 1.130 \\
\end{tabular}

a. Test distribution is Normal.

b. Calculated from data.

Sesuai dengan hasil penelitian pada tabel di atas diketahui bahwa nilai tabel lebih besar dari nilai signifikansi 0.05 sehingga dapat diartikan data yang diuji berdistribusi normal.

b. Uji Multikolinearitas

Coefficients $^{\mathrm{a}}$

\begin{tabular}{|c|c|c|c|c|c|c|c|}
\hline \multirow{2}{*}{ Model } & \multicolumn{2}{|c|}{$\begin{array}{l}\text { Unstandardized } \\
\text { Coefficients }\end{array}$} & \multirow{2}{*}{$\begin{array}{c}\begin{array}{c}\text { Standardi } \\
\text { zed } \\
\text { Coefficien } \\
\text { ts }\end{array} \\
\text { Beta }\end{array}$} & \multirow{2}{*}{$\mathbf{T}$} & \multirow{2}{*}{ Sig. } & \multicolumn{2}{|c|}{ Collinearity Statistics } \\
\hline & B & $\begin{array}{l}\text { Std. } \\
\text { Error }\end{array}$ & & & & Tolerance & VIF \\
\hline $\begin{array}{c}\text { (Consta } \\
\text { nt) }\end{array}$ & 18.703 & 6.234 & & 3.000 & 0.004 & & \\
\hline PP & -0.158 & 0.195 & -0.087 & -0.810 & 0.421 & 0.969 & 1.032 \\
\hline $\mathrm{PO}$ & 0.173 & 0.198 & 0.096 & 0.874 & 0.386 & 0.917 & 1.090 \\
\hline PDTA & 0.593 & 0.111 & 0.586 & 5.359 & 0.000 & 0.924 & 1.082 \\
\hline
\end{tabular}

a. Dependent Variable: PADPKD

Berdasar tabel di atas, nilai tolerance variabel pendidikan dan pelatihan (PP) 0.969, pengalaman organisasi (PO) 0.917, dan pemahaman tentang anggaran (PDTA) 0.924 lebih besar dari 0.10. Sementara itu, Nilai VIF dari variabel pendidikan dan pelatihan (PP) 1.032, pengalaman organisasi (PO) 1.090, dan pemahaman anggota DPRD tentang anggaran (PDTA) 1.082 lebih kecil dari 10.00. Sehingga dapat disimpulkan tidak terjadi multikolinearitas. 
c.Uji Heteroskedastisitas

Coefficients $^{\mathrm{a}}$

\begin{tabular}{|c|c|c|c|c|c|c|}
\hline & \multirow[t]{2}{*}{ Model } & \multicolumn{2}{|c|}{$\begin{array}{c}\text { Unstandardized } \\
\text { Coefficients }\end{array}$} & $\begin{array}{l}\text { Standardized } \\
\text { Coefficients }\end{array}$ & \multirow[t]{2}{*}{$t$} & \multirow[t]{2}{*}{ Sig. } \\
\hline & & B & Std. Error & Beta & & \\
\hline & (Constant) & 17.750 & 3.826 & & 4.640 & 0.000 \\
\hline 1 & PP & -0.288 & 0.120 & -0.286 & -2.399 & 0.020 \\
\hline & PO & -0.302 & 0.121 & -0.305 & -2.493 & 0.016 \\
\hline & PDTA & -0.107 & 0.068 & -0.193 & -1.577 & 0.120 \\
\hline
\end{tabular}

a. Dependent Variable: RES2

Berdasar tabel di atas bahwa nilai signifikansi variabel pendidikan dan pelatihan (PP) sebesar 0.020, variabel pengalaman organisasi (PO) sebesar 0.016, dan variabel pemahaman anggota DPRD tentang anggaran sebesar 0.120 dimana nilai signifikansi semua variabel di atas lebih besar dari 0.05. Itu artinya bahwa tidak terjadi heteroskedastisitas.

\subsubsection{Analisis Regresi Linear Berganda}

a. Uji t

Coefficients $^{\mathrm{a}}$

\begin{tabular}{|c|c|c|c|c|c|c|}
\hline & \multirow[t]{2}{*}{ Model } & \multicolumn{2}{|c|}{$\begin{array}{l}\text { Unstandardized } \\
\text { Coefficients }\end{array}$} & \multirow{2}{*}{$\begin{array}{c}\begin{array}{c}\text { Standardize } \\
\text { d } \\
\text { Coefficients }\end{array} \\
\text { Beta }\end{array}$} & \multirow[t]{2}{*}{$\mathbf{t}$} & \multirow[t]{2}{*}{ Sig. } \\
\hline & & B & Std. Error & & & \\
\hline & (Constant) & 18.703 & 6.234 & & 3.000 & 0.004 \\
\hline & PP & -0.158 & 0.195 & -0.087 & -0.810 & 0.421 \\
\hline $\mathbf{I}$ & $\mathrm{PO}$ & 0.173 & 0.198 & 0.096 & 0.874 & 0.386 \\
\hline & PDTA & 0.593 & 0.111 & 0.586 & 5.359 & 0.000 \\
\hline
\end{tabular}

a. Dependent Variable: PADPKD

Melihat output di atas terdapat tiga hipotesis di ajukan dalam uji t:

1. $\mathrm{H}_{1}=$ Pendidikan dan Pelatihan (X1) berpengaruh secara signifikan terhadap peran anggota DPRD dalam pengawasan keuangan daerah.

2. $\mathrm{H}_{2}=$ Pengalaman Organisasi (X2) berpengaruh secara signifikan terhadap peran anggota DPRD dalam pengawasan keuangan daerah.

3. $\mathrm{H}_{3}=$ Pemahaman anggota DPRD tentang Anggaran (X3) berpengaruh secara signifikan terhadap peran anggota DPRD dalam pengawasan keuangan daerah.

Hasil uji parsial (Uji t) untuk hipotesis pertama bahwa nilai koefisien variabel X1 adalah sebesar -0.158 , dan t hitung variabel $\mathrm{X} 1$ adalah -0.810 dengan nilai signifikansi 0.421 . Kemudian nilai t tabel untuk uji parsial ini dengan df $=\mathrm{n}-\mathrm{k}-1=60-3-1=56$ pada level 0.05 adalah sebesar 1.673. Karena t hitung lebih kecil daripada t tabel, dan nilai signifikansi lebih dari 0,05 maka $\mathrm{H}_{1}$ di tolak. Dengan demikian dapat disimpulkan bahwa hipotesis pertama diterima.

Hasil pengujian parsial (Uji t) untuk hipotesis kedua menunjukan bahwa nilai koefisien variabel X2 adalah sebesar 0,173, dan t hitung variabel X1 adalah 0,874 dengan nilai signifikansi 0,386. Kemudian nilai t tabel untuk uji parsial ini dengan df $=n-k-1=60-3-$ $1=56$ pada level 0,05 adalah sebesar 1,673. Karena t hitung lebih kecil daripada $t$ tabel, dan nilai signifikansi lebih dari 0,05 maka $\mathrm{H}_{2}$ di tolak. Dengan demikian dapat disimpulkan bahwa hipotesis kedua diterima. 
Hasil uji parsial (Uji t) untuk hipotesis ketiga menunjukan nilai koefisien variabel $\mathrm{X} 3$ adalah sebesar 0,593, dan t hitung variabel $\mathrm{X} 3$ adalah 5,359 dengan nilai signifikansi 0,000. Kemudian nilai t tabel untuk uji parsial ini dengan $\mathrm{df}=\mathrm{n}-\mathrm{k}-1=60-3-1=56$ pada level 0,05 adalah sebesar 1,673. Karena t hitung lebih besar dari t tabel, dan nilai signifikansi kurang dari 0,05 maka $\mathrm{H}_{3}$ diterima. Dengan demikian dapat disimpulkan bahwa hipotesis ketiga diterima.

b. Anaisis Regresi Linier Berganda

Berdasarkan tabel di atas diperoleh nilai konstan sebesar 18,703, koefisien variabel pendidikan dan pelatihan (PP) sebesar $-0,158$, koefisien variabel pengalaman organisasi (PO) sebesar 0,173, dan koefisien variabel pemahaman anggota DPRD tentang anggaran (PDTA) sebesar 0,593. Jadi persamaan regresi linear berganda penelitian ini adalah :



1. Konstanta 18,703 menunjukan bahwa diluar variabel pendidikan dan pelatihan (PP), pengalaman organisasi (PO), pemahaman anggota DPRD tentang anggaran (PDTA) yang diteliti masih terdapat variabel lain yang mempengaruhi peran anggota DPRD dalam pengawasan keuangan daerah.

2. Jika nilai variabel pendidikan dan pelatihan (PP) meningkat sebesar 1 satuan sedangkan nilai variabel lain tetap, maka tidak akan secara signifikan mengakibatkan turun nilai variabel peran anggota DPRD dalam pengawasan keuangan daerah (PADPKD) sebesar 0,158 .

3. Jika nilai variabel pengalaman organisasi (PO) meningkat sebesar 1 satuan sedangkan nilai variabel lain tetap, maka tidak akan secara signifikan mengakibatkan meningkatnya nilai variabel peran anggota DPRD dalam pengawasan keuangan daerah (PADPKD) sebesar 0.173 .

4. Jika nilai variabel pemahaman anggota DPRD tentang anggaran (PDTA) meningkat sebesar 1 satuan sedangkan nilai variabel lain tetap, maka secara signifikan akan mengakibatkan meningkatnya nilai variabel peran anggota DPRD dalam pengawasan keuangan daerah (PADPKD) sebesar 0.593.

\subsection{Pembahasan}

\subsubsection{Pengaruh pendidikan dan pelatihan terhadap peran anggota DPRD dalam pengawasan keuangan daerah}

Pada penelitian ini variabel pendidikan dan pelatihan tidak pengaruh terhadap peran anggota DPRD dalam pengawasan keuangan daerah. Kesimpulan penelitian bahwa variabel pendidikan dan pelatihan tidak mempengaruhi peran anggota DPRD dalam pengawasan keuangan daerah. Ini penyebabnya karena data didapatkan dari responden pada variabel pendidikan dan pelatihan ini telah ditemukan suatu temuan yaitu sebagian besar responden yang mempunyai kriteria pendidikan dan pelatihan tergolong pada kategori baik, mengisi pernyataan pada variabel peran anggota DPRD dalam pengawasan keuangan daerah dengan skor rendah atau responden yang mempunyai pendidikan dan pelatihan yang rendah justru 
mengisi pernyataan pada variabel peran anggota DPRD dalam pengawasan keuangan daerah dengan skor tinggi.

Pendidikan dan pelatihan tidak berpengaruh terhadap peran anggota DPRD dalam pengawasan keuangan daerah. Diduga seseorang yang memiliki pendidikan yang baik cenderung untuk mengesampingkan tugas dan fungsinya, sehingga hal ini menyebabkan peran seseorang tersebut menjadi tidak baik. Seperti pada fungsi pengawasan, seorang anggota dewan yang mempunyai pendidikan yang baik, cenderung lebih mengesampingkan tugas dan fungsi utamanya, yaitu melaksanakan fungsi pengawasan. Selain itu, seluruh anggota dewan mempunyai tugas dan wewenang yang sama ketika melakukan peran pengawasan keuangan daerah dan juga persebaran demografinya tidak merata.

Hasil penelitian ini sejalan dengan penelitian yang dilakukan oleh Kartikasari (2012) dan Amalia (2013) yang menyatakan bahwa pendidikan dan pelatihan tidak berpengaruh terhadap peran anggota DPRD dalam pengawasan keuangan daerah.

\subsubsection{Pengaruh pengalaman organisasi terhadap peran anggota DPRD dalam pengawasan keuangan daerah}

Pada penelitian ini pengalaman organisasi tidak berpengaruh terhadap peran anggota DPRD dalam pengawasan keuangan daerah. Hal ini disebabkan karena pengalaman orgnanisasi merupakan proses belajar seseorang dan kemungkinan dalam proses belajar dalam organisasi tersebut, seseorang mengalami proses belajar yang tidak sehat sehingga mengakibatkan seseorang tersebut tidak dapat mengaplikasikan hasil belajarnya tersebut untuk menunjang pelaksanaan tugas, seperti pengalaman yang telah didapat oleh anggota DPRD tidak diaplikasikan dengan baik dalam melaksanakan salah satu fungsi DPRD yaitu melaksanakan fungsi pengawasan, sehingga mengakibatkan pengalaman organisasi tidak berpengaruh terhadap peran anggota DPRD dalam pengawasan keuangan daerah.

Hasil penelitian ini sejalan dengan penelitian yang dilakukan oleh Amalia (2013) yang menyatakan bahwa pengalaman organisasi tidak berpengaruh terhadap peran anggota DPRD dalam pengawasan keuangan daerah.

\subsubsection{Pengaruh pemahaman anggota DPRD tentang anggaran terhadap peran anggota DPRD dalam pengawasan keuangan daerah}

Pada penelitian ini pemahaman anggota DPRD tentang anggaran berpengaruh positif dan signifikan terhadap peran anggota DPRD dalam pengawasan keuangan daerah. Penyebabnya karena berdasarkan hasil pengujian terhadap jawaban responden, menunjukan hasil bahwa anggota DPRD mempunyai pengetahuan tentang anggaran dengan baik atau tinggi. Anggota DPRD mengetahui keseluruhan mekanisme susun anggaran mulai tahap perencanaan sampai tahap pertanggungjawaban serta anggota DPRD mengetahui peraturan perUUan yang atur pengelolaan keuangan daerah APBD. Fungsi-fungsi yang dimiliki oleh DPRD seperti fungsi penganggaran dan fungsi pengawasan sangat erat hubungannya dengan pemahaman anggota DPRD tentang anggaran/APBD, dimana APBD sebagai objek untuk melaksanakan fungsi DPRD tersebut.

Hasil dari penelitian ini sejalan dengan penelitian Dewi (2011) dan Amalia (2013) bahwa pemahaman anggota DPRD tentang anggaran berpengaruh terhadap peran anggota DPRD dalam pengawasan keuangan daerah.

\section{KESIMPULAN DAN SARAN}

\subsection{Kesimpulan}

Simpulan yang dapat diambil pada penelitian ini antara lain :

1. Pendidikan dan pelatihan tidak berpengaruh signifikan terhadap peran anggota DPRD dalam pengawasan keuangan daerah. Pada DPRD tidak ada tingkat jabatan berdasar pada tingkat pendidikan dan pelatihan yang dimiliki. Seluruh anggota dewan mempunyai tugas dan wewenang yang sama dalam melakukan peran pengawasan keuangan daerah. 
2. Pengalaman organisasi tidak berpengaruh signifikan terhadap peran anggota DPRD dalam pengawasan keuangan daerah. Jika seseorang mengalami proses belajar yang tidak sehat sehingga mengakibatkan seseorang tersebut tidak dapat mengaplikasikan hasil belajarnya tersebut untuk menunjang pelaksanaan tugas.

3. Pemahaman anggota DPRD mengenai anggaran memberikan pengaruh yang positif terhadap peran anggota DPRD terhadap pengawasan keuangan daerah. Anggota DPRD harus memahami dan melaksanakan penyusunan anggaran mulai dari perencanaan sampai pertanggungjawaban serta anggota DPRD mengetahui tentang aturan UU yang mengatur pengelolaan keuangan daerah APBD.

\subsection{Saran}

Saran yang penulis ajukan berdasarkan hasil penelitian ini adalah sebagai berikut :

1. Hasil penelitian ini variabel pendidikan dan pelatihan, dan pengalaman organisasi tidak berpengaruh signifikan, hal ini kemungkinan disebabkan karena instrumen yang digunakan merupakan instrumen baru. Pada penelitian mendatang, hendaknya instrumen penelitian untuk variabel tersebut perlu dikembangkan atau dapat mencari intstrumen yang lain.

2. Bagi peneliti selanjutnya diharapkan mempertimbangkan variabel lain yang mungkin dapat mempengaruhi pengawasan keuangan daerah.

\section{DAFTAR PUSTAKA}

Amalia, 2013. Faktor-faktor yang Mempengaruhi Peran DPRD dalam Pengawasan Keuangan Daerah (Studi kasus pada DPRD kab. Purworejo). Fakultas Ekonomi Universitas Negeri Semarang, Semarang.

Dewi, Indah Mustika. 2011. "Analisis Faktor-Faktor yang Mempengaruhi Kapablitas Anggota DPRD Dalam Pengawasan Keuangan Daerah (APBD)". Skripsi. Semarang: Universitas Diponegoro.

Halim, et al. 2014. Akuntansi Sektor Publik, Pengertian Akuntansi Pemerintahan. Pustaka Baru Press.

Kartikasari, Dewi. 2012. "Pengaruh Personal Background, Political Background, Pemahaman Regulasi Terhadap Peran Anggota DPRD Dalam Pengawasan Keuangan Daerah (Studi Kasus pada DPRD Kabupaten Boyolali)”. Accounting Analysis Journal. Semarang: Universitas Negeri Semarang.

Keputusan Presiden Republik Indonesia No. 74 tahun 2001 tentang Tata Cara Pengawasan Penyelenggaraan Pemerintahan Daerah. Jakarta: Keputusan Presiden Republik Indonesia.

Keputusan Presiden Republik Indonesia Nomor 74 Tahun 2001 tentang Tata Cara Pengawasan Penyelenggaraan Pemerintah Daerah. Jakarta: Keputusan Presiden Republik Indonesia.

Republik Indonesia. 2003. UU Nomor 17 Tahun 2003 pasal 3 ayat (4) tentang Keuangan Negara. Jakarta: Republik Indonesia.

Republik Indonesia. 2003. UU Nomor 20 Tahun 2003 tentang Sistem Pendidikan Nasional. Jakarta: Republik Indonesia

Republik Indonesia. 2003. UU Nomor 22 Tahun 2003 pasal 77 tentang Susunan dan Kedudukan MPR, DPR, DPD, dan DPRD. Jakarta: Republik Indonesia.

Republik Indonesia. 2014. UU Nomor 23 Tahun 2014 pasal 149 tentang Pemerintahan Daerah. Jakarta: Republik Indonesia.

Republik Indonesia. 2014. UU Nomor 23 Tahun 2014 pasal 154 tentang Pemerintahan Daerah. Jakarta: Republik Indonesia. 